BULLETIN Bulletin hispanique

HispaniquE Université Michel de Montaigne Bordeaux

113-1 | 2011

Actes de 2 colloques

\title{
Cantos al sacro epitalamio o sea pliegos poéticos para las tomas de velo
}

Deslindes preliminares

\section{Nieves Baranda Leturio}

\section{OpenEdition}

\section{Journals}

Edición electrónica

URL: http://journals.openedition.org/bulletinhispanique/1345

DOI: 10.4000/bulletinhispanique.1345

ISSN: 1775-3821

\section{Editor}

Presses universitaires de Bordeaux

\section{Edición impresa}

Fecha de publicación: 1 junio 2011

Paginación: 269-296

ISBN: 978-2-86781-740-3

ISSN: 0007-4640

\section{Referencia electrónica}

Nieves Baranda Leturio, «Cantos al sacro epitalamio o sea pliegos poéticos para las tomas de velo », Bulletin hispanique [En línea], 113-1 | 2011, Publicado el 01 junio 2014, consultado el 19 abril 2019.

URL : http://journals.openedition.org/bulletinhispanique/1345; DOI : 10.4000/bulletinhispanique.1345 


\title{
Cantos al sacro epitalamio o sea pliegos poéticos para las tomas de velo. Deslindes preliminares ${ }^{1}$
}

\author{
Nieves Baranda Leturio \\ Universidad Nacional de Educación a Distancia (UNED) - España
}

Première étude des pliegos sueltos de villancicos imprimés en Espagne jusqu'en 1749 pour célébrer les prises de voile dans les couvents de femmes. L'auteure a réuni 182 pliegos dont elle analyse les dates et les lieux d'impression, les caractéristiques, l'usage et les contenus pour définir quelques éléments fondamentaux de ce sous-genre poétique.

Estudio inaugural de los pliegos sueltos de villancicos impresos en España hasta 1749 con motivo de las profesiones religiosas en conventos femeninos. La autora ha recopilado 182 pliegos y analiza las fechas y lugares de impresión, las caracteristicas de los impresos, su uso y los contenidos de su poesía para establecer algunos elementos esenciales del subgénero.

This paper is an opening study on the poetic chapbooks "pliegos sueltos " of villancicos printed in Spain until 1749 to celebrate religious professions in nun's convents. The author analyzes the printing dates and locations, the uses, the features and some of the main poetic topics of the 182 items collected by her, in order to define some of the essential aspects of this devotional subgenre.

Mots-clés: Pliegos sueltos - Chants sacrés - Musique religieuse - Culture conventuelle - Poésie et société.

1. Este artículo es parte de los resultados del proyecto BIESES, financiado por el Ministerio de Ciencia e Innovación (FFI2009-08517). Referencias bibliográficas sobre las escritoras pueden consultarse en la base de datos del proyecto: http://www.uned.es/bieses.

Bulletin Hispanique, Tome 113, n 1 - juin 2011 - p. 269 à 296. 
A poesía escrita para la celebración de profesiones es uno de los subgéneros frecuente en las escritoras conventuales más prolíficas. Podríamos remontar su inicio conocido a Teresa de Jesús, que entre sus 28 poesías tiene cinco dedicadas a las profesiones. Cuatro son villancicos para uso colectivo, se inician con un estribillo y se desarrollan con varias coplas, uno de ellos en verso hexasilábico. El cuarto poema tiene una finalidad particular y es de otro género: "Glosa que nuestra santa madre Teresa de Jesús hizo al velo de la hermana Isabel de los Ángeles. En Salamanca, 1571» (Teresa de Jesús, 2000: 1172-1177). Esta tradición compositiva se perpetúa en el Carmelo: Ana de San Bartolomé la llevó a las tomas de velo en Amberes (1998: 779-783)²; María de San José Salazar a Portugal (Manero Sorolla, 1992: 207-208) y compuso dos villancicos: «Una hermana lusitana / hoy se viste de sayal», dedicado a la primera descalza portuguesa, María de Castelbranco (María de Jesús en el claustro), sobrina del Conde de Sabugal, y «Unas cordericas / van tras su pastor» ${ }^{3}$; Cecilia del Nacimiento compuso una fiestecilla para una profesión religiosa y posiblemente otro de sus poemas, el que comienza "Zagala muy bien se paga / lo que habéis estado herida", podría ser también para una celebración de este tipo, a juzgar por su tema (1971: 639-654, 660) ${ }^{4}$. Marcia Belisarda, religiosa en el convento de la Concepción Francisca de Toledo, compuso para la profesión de Petronila de Palma un soneto y una décima: «A la profession de dońa Petronila de la Palma en la Concepçion Real de Toledo siguiendo la metáfora de la Palma»; y un romance «A la professión de una monja bernarda que la hizo en día de la degollaçión del baptista estando el Santíssimo sacramento descubierto y su nombre Paula» (Manuscrito, s.a.: 7v.-8r., 14r.). En la edición de las obras de Violante do Ceo, del Convento dominico de Nossa Senhora da Rosa, en Lisboa, hay villancicos para estas celebraciones, que por su fama posiblemente fueran encargados desde otros monasterios lisboetas porque no se limita a las monjas de su convento ${ }^{5}$. En México sor Juana Inés de la

2. Con este y otros escritos las carmelitas descalzas fundadoras ejercían de agentes culturales españoles en tierras extranjeras, exportando las modas de su Castilla natal.

3. Incluidos en Melchor de Santa Ana (1657, 134-135); además escribió una canción de bienvenida para ser cantada a dos dominicas que fueron acogidas en el carmen durante el asedio de Drake a Lisboa.

4. No se recoge ninguna composición de este género entre las obras de su hermana María de San Alberto, aunque según un testimonio dice de ella: «nos cantaba... las coplitas que entonces había hecho para sus hábitos y profesiones, que eran de harto espíritu y recreación para todas, y más era la gracia con que ella lo hacía» (Schlau 1998: 23).

5. Todos ellos se editan seguidos en Parnaso lusitano (Violante do Ceo, 1732-1733: II, 1061-1102): villancicos a la profesión de Ana de la Luz, Margarita de Silva, Juana de Sosa, hija del Conde de Prado, Beatriz de San Juan, Margarita de la Cruz, Beatriz de los 
Cruz, ilustre villanciquera para otros festejos, solo parece haber escrito para una profesión religiosa, si bien son cuatro letras, lo que componía un juego para cantar en distintos momentos de la ceremonia, por ejemplo la letra III se titula «De las antífonas» (1952: II, 228-232).

Aunque eran piezas para celebrar ceremonias femeninas, la composición de estos poemas también recayó en muchos poetas (hombres), que en algunos casos llegaron a convertirse en auténticos expertos. A modo de ejemplo, se podría recordar las muchas poesías de González de Eslava, que tenía entre las monjas la principal clientela de sus poemas (1989: 71-75) en los años 80 del siglo XVI; las composiciones bien conocidas de Vicente Sánchez incluidas en la Lira poética (2003: 219-244), las del famoso León Marchante, que figuran en sus obras ${ }^{6}$, o las del humilde Gonzalo Enríquez de Arana para las monjas de Santa Clara de Montilla (Cruz Casado, 1997: 338-346).

Para la celebración de las profesiones se emplearon géneros diferentes. Por un lado los textos paradramáticos (loas, sobre todo) que se interpretaban en la fiesta privada para el interior del convento, al modo de los que compusieron sor Cecilia del Nacimiento, sor Marcela de san Félix o sor Francisca de Santa Teresa (Alarcón Román, 2007: 95-114; Hormigón, 1996); por otro los poéticos: romances, letras o villancicos, que musicados se incorporaban a la ceremonia religiosa. No obstante, no se limitaron a géneros tradicionales, porque Cecilia del Nacimiento compuso liras, octavas o tercetos, recogidos en el Libro de romances y coplas del Carmelo de Valladolid (García de la Concha / Pellitero, 1982: no 202, 218, 217 y 221); y Violante do Ceo un soneto y una canción (1732-1733: I, 110-112). No obstante, estas formas cultas fueron minoritarias y el villancico, que ya estaba integrado en la tradición musical litúrgica, será el que predomine con sus muchas variantes.

El rastro de esos villancicos para la interpretación musical no solo ha quedado en compilaciones de poemas o en cancioneros profesionales, sino también y de forma muy significativa en una rica tradición de pliegos sueltos. A pesar de su abundancia no han llamado particular atención de los investigadores, perdidos en medio de la masiva literatura de cordel a

Serafines, una religiosa, dos hermanas, Francisca Henriques, Laurencia de Castro, Francisca del Sacramento (4 villancicos), Clara de San José y Rosa María, Antonia María, Teresa de la Cruz (2 villancicos), Blanca del Espíritu Santo, Violante María (2 villancicos).

6. Son cinco poemas, cada uno de ellos a la profesión de una religiosa distinta y para conventos diversos de Alcalá de Henares, sobre todo: romance a la profesión de dońa Teresa Rosa, carmelita descalza; a la de Teresa Estrada en el convento de carmelitas descalzas de Alcalá, a Inés en el convento de agustinas de Alcalá; a Bernarda de la Flor, en la Concepción Francisca, a la profesión de doña Bárbara (León Marchante, 1733: 375-79). 
lo divino que inundó los mercados españoles, como parte de la batería de medios para el adoctrinamiento (misiones internas, predicaciones, cofradías, lecturas, festejos...) que pretenden colmar el espacio público vocal, para hacer también de la calle un lugar de catequesis, propaganda religiosa y moralidad. Se diferencian en este aspecto de los pliegos de villancicos para celebraciones navideñas o para las festividades del santoral, estudiados como la parte destacada de esta literatura del menudeo. Según García de Enterría (1989: 148-149) la costumbre de que las iglesias o instituciones de categoría publicaran pliegos navideńos se desarrolla paulatinamente a lo largo del siglo XVI y, hacia el segundo decenio del siglo XVII, ya se puede considerar un uso establecido, si bien no demasiado extendido. Será en los años del reinado de Carlos II (1665-1700) cuando el fenómeno de estas ediciones eclosione y se vuelvan masivas, así lo atestiguan los muchos restos que nos han llegado, no solo en bibliotecas públicas de inventario conocido, sino por los aún guardados en conventos, archivos catedralicios, iglesias, etc. Seguramente estemos, por un lado, ante un fenómeno de sustitución, por el cual estos pliegos ocupan en parte el espacio mercantil y social que antes ocupaban los pliegos poéticos profanos, pero también de intensificación de esta literatura de cordel en su conjunto. Las grandes catedrales españolas, los conventos como las Descalzas, La Encarnación de Madrid o El Escorial, otras iglesias, etc. celebran estas festividades con música popular en lengua romance y la imprimen para sus fieles. Sus títulos sugieren que inicialmente se imprimían para ser vendidos después de la ceremonia, de ahí que hasta mediado el siglo XVII en el título se ponga "que se cantaron», mientras que en torno a esas fechas se produce un cambio, ya que los títulos empiezan a poner "que se cantarán", dando a entender que el pliego se compone antes del acto litúrgico y para que se pueda seguir éste, seguramente para facilitar la comprensión de los textos además de obtener algunos beneficios de su venta al público, aunque se regalen a las autoridades presentes. Si es de creer en su función de pedagogía religiosa, a propósito de la vida del santo que se cantaba o el simbolismo fundamental de la navidad, por ejemplo, no es menor la proyección social e institucional que se podía ejercer a través de su difusión. Al igual que las relaciones de fiestas, el pliego se convierte en el testimonio escrito, por lo tanto permanente, de un hecho efímero, en el que una comunidad desea plasmar su prestigio con el mejor despliegue posible de recursos.

Los actos que se consignan a través de estos pliegos no son hechos singulares que puedan ser sometidos a una narración bastante variada para incitar a la lectura. La liturgia es ante todo repetición y no ofrece alicientes narrativos, sin embargo, los villancicos, en tanto que piezas poéticas 
populares, sí pueden ofrecer atractivos para el público, que puede proyectar elementos cantados de la ceremonia sobre la institución a la que textual y socialmente se vinculan, contribuyendo a su prestigio y al conocimiento de sus actividades. Los pliegos de villancicos ejercen para estos actos litúrgicos funciones similares a las del pliego de relación festiva: perpetúan su continuidad en la historia y la memoria colectiva proyectando la institución organizadora de un modo prestigioso sobre la sociedad de su entorno. Sin duda mantener viva esa memoria no era necesariamente el único objetivo, menos en una época de empobrecimiento general, así García de Enterría (1994-1996: 130) cree que estos pliegos suponían beneficios económicos para impresores e instituciones. Existen testimonios sobre su venta a manos de ciegos a la puerta de las iglesias:

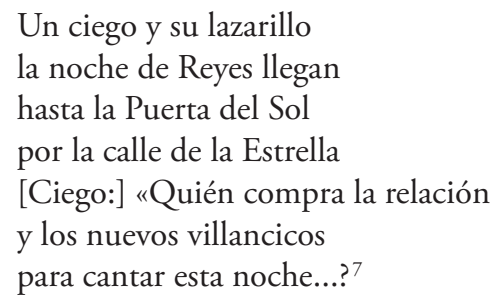

Por otro lado, el anuncio de que ese acto se iba a celebrar con su fecha precisa (y era así en algunos casos) podía atraer mucho público a la iglesia, lo que no era de menor importancia en su potencial efecto sobre las limosnas.

\section{FECHAS Y LUGARES DE PRODUCCIÓN}

Los pliegos de profesión religiosa tienen un carácter distinto a los de grandes celebraciones festivas o institucionales, sin embargo por su fecha de aparición, es necesario creer que aprovecharon para su desarrollo el cauce textual de los villancicos navideños y los imitaron, pues si éstos eclosionan en el reinado de Carlos II, los de profesiones se consolidan dos decenios después, según se verá. Cuando Juana de Austria redacta en 1572 la escritura de fundación del Monasterio de las Descalzas Reales, organiza la capilla musical al estilo de las capillas reales y, entre otras instrucciones, establece las ceremonias en las que se debe dar solemnidad con la música: pascuas y sus vísperas (navidad, reyes, resurrección y pentecostés), las pascuas y vísperas de Sabaoth y de nuestra seńora, san Juan Bautista, san Sebastián, las once

7. Apud García de Enterría (1994-1996: 130). 
mil vírgenes, del ángel de la guarda y las celebraciones de toma de velo y de profesión (Sánchez Sicart, 2001: 35). Los villancicos para las profesiones estaban, como los navideños, destinados a un acto litúrgico de carácter comunitario, donde la música en romance era parte de una celebración festiva. Como en la navidad, esa música que se creaba para el acto podía tener una pervivencia impresa más allá de la celebración y fuera cual fuera la finalidad de la pieza en papel debemos atribuirle una función social. Entre los 182 pliegos anteriores a 1750 que en la actualidad forman mi $\operatorname{corpus}^{8}$ se observa que es en el decenio de 1670 cuando la tendencia adquiere cierto desarrollo, puesto que los publicados anteriormente se muestran cronológicamente aislados. El primero está impreso en 1634 en Montilla para la profesión de la hija de los Marqueses de Priego en el convento de Santa Clara, del que la familia tenía el patronazgo y donde profesaban muchas de sus mujeres? El segundo se publica en 1644 para la profesión en el Real monasterio de Trasobares (Aragón) de Ana María de Sayas, hija de Francisco Diego de Sayas, cronista de la Almunia de dońa Godina ${ }^{10}$. En Zaragoza con motivo de la toma de hábito y de la profesión de Josefa Manuela de Palafox y Cardona, hija de los marqueses de Ariza, en el convento de Capuchinas de Zaragoza se publicaron dos pliegos distintos y en años sucesivos 1665 y 1666, que contenían «Letras de varios ingenios..." ${ }^{11}$. Aunque también para una toma

8. El primero es del año 1634. Se ha establecido 1749 como límite ante quem para atenerse al marco cronológico del coloquio, si bien el fenómeno de estos impresos se prolonga mucho más en el tiempo y la búsqueda deberá continuarse. La relación de piezas recopilada no ha pretendido ser exhaustiva, aunque se han consultado los principales catálogos de villancicos: Biblioteca Nacional, bibliotecas británicas, Nueva York (Cátalogo, 1990; Catálogo, 1992, Torrente, 2000; Torrente / Hathaway, 2007). Otros muchos están en fondos que aún no cuentan con un catálogo especializado. Es especialmente rico el de la Biblioteca de la Universidad de Barcelona, donde he encontrado 57 piezas. Otros fondos significativos, aunque menores, están en la Biblioteca de Catalunya, 19 pliegos; la Biblioteca pública de Montpellier, 9 pliegos; y el archivo histórico de Cervera, 7 pliegos. La labor de búsqueda en ningún caso se puede dar por concluida y hasta las últimas etapas de revisión de este trabajo han aparecido pliegos que han obligado a retocar los números / gráficos constantemente, no tanto por la modificación de las conclusiones como por rigor metodológico. Sería deseable contar con una bibliografía sistemática del género, que incluyera tanto las profesiones religiosas como los matrimonios. Como término comparativo se pueden recordar las de Pinto (1971), Mazzucco (1985) y Bosi (1995), que dejan comparativamente muy cortos los números españoles.

9. Madrid, Biblioteca Nacional, R/12176-9. El pliego, por sus características, está más destinado a la exaltación del linaje que a la celebración de la profesa.

10. Zaragoza, Universidad, Caja 75-1727 Ar. Sobre la familia Sayas vid. Zaragoza Ayarza (2009).

11. Letras de varios ingenios, que se cantaron el día de los SS. Apóstoles San Felipe y Santiago, en el religiosísimo Convento de Nuestra Señora de los Ángeles y Madres Capuchinas de Çaragoça, 
de velo, tiene un contenido distinto Preseas de penitencia y joyas de una esposa religiosa, en idea de varios matizes de letras mýsticas: sermon en la profesión y velo de Sor Juana de la Cruz y Pacheco... ${ }^{12}$, ya que incluye el sermón del acto, lo que sitúa el impreso a medio camino entre el pliego poético de profesión, que nos interesa, y modalidades panegíricas que no hemos tenido en cuenta, si bien se podrían sumar ambas tipologías para tener una idea cabal de la literatura en torno a estos actos religiosos.

La modalidad más conocida de pliego de profesión sufre un incremento muy significativo en los años 80 , frente a los decenios anteriores donde hay apenas dos muestras en cada caso. Durante los años 1690-99 la popularidad de estos pliegos es ya muy notable y se mantendrá en un número elevado hasta nuestra fecha límite, aunque se observa claramente un descenso en el decenio 1720-1729 como efecto de la guerra de sucesión, que tuvo un fuerte impacto en la industria en general y en la imprenta ${ }^{13}$.

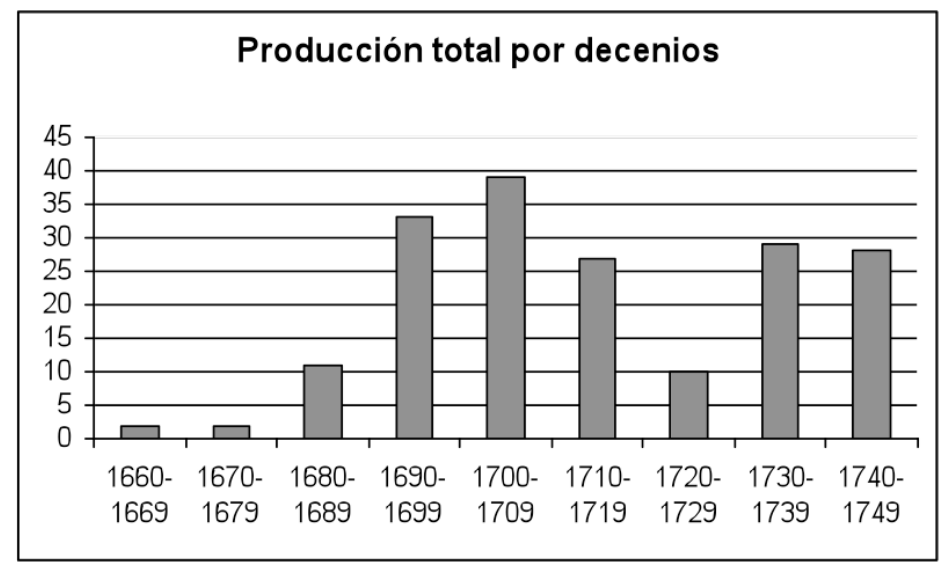

al recibir el hábito en él, mi Señora doña Iosepha de Palafox y Cardona, hija de los Illustríssimos Señores Marqueses de Ariza, Zaragoza, s.i., 1665.; y Letras de varios ingenios que se cantaron a quatro de enero de 1666 en el religiosíssimo convento de nuestra señora de los Ángeles y madres capuchinas de Çaragoça, en la profession de la madre sor Iosepha-Manuela de Palafox y Cardona, hija de los illustrissimos señores marqueses de Ariza, Zaragoza, 1666. Pliegos citados por Serra de Manresa, (2002: pp. 41-42), sin localización.

12. Alcalá de Henares: Imprenta de la universidad, 1674, 23 pp. Impreso no consultado, reseñado en el catálogo colectivo del patrimonio bibliográfico (CCPB, en adelante). El título no parece afirmar que las letras místicas se cantaran en la ceremonia. Tejera (1922: 181-182) dice del autor, P. José Corvalán, y la pieza: «Un Sermón en la profesión de una Religiosa llamada sor Juana de la Cruz y Pacheco, Clarisa Descalza en el Real Monasterio de Almonacid de Zurila, hermana del Duque de Estrada, etc., que predicó el año de 1674 y se dio a la prensa en Alcalá de Henares el mismo año».

13. Así lo demuestran los datos manejados por Jean-Marc Buigues para otros impresos, tal como me apuntó en el coloquio. 
No obstante, para afinar la percepción de un corte tan brusco en la tendencia se puede acudir a un gráfico por quinquenios, donde se constata que el descenso, en realidad, corresponde a un período de quince años, entre 171529 y no solo al decenio 1720-1729. Por otro lado, no es tan súbito como se podría pensar y tampoco corresponde exactamente a los ańos de la guerra, sino a la posguerra, posiblemente por la falta generalizada de recursos.

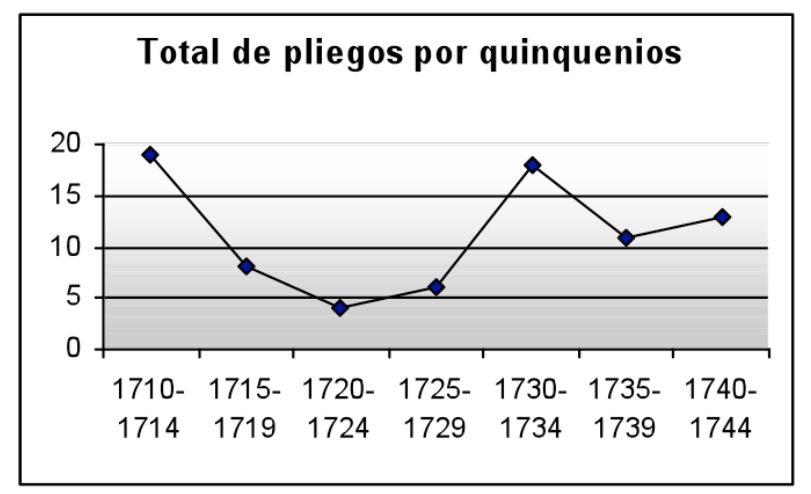

Estas cifras absolutas para el territorio peninsular ocultan que, en realidad, son los conventos de Zaragoza y Barcelona los lugares donde se concentra la producción. Ya las primeras apariciones de estos pliegos son en ciudades del reino de Aragón -los dos que en 1665 y 1666 se hicieron a la hija de los marqueses de Ariza en Zaragoza- y seguirán siendo los lugares donde se mantengan esos pliegos celebrativos a lo largo de todo el período, según podemos observar en el cuadro que representa la evolución cronológica de ambos centros en comparación con el resto de lugares de la península.

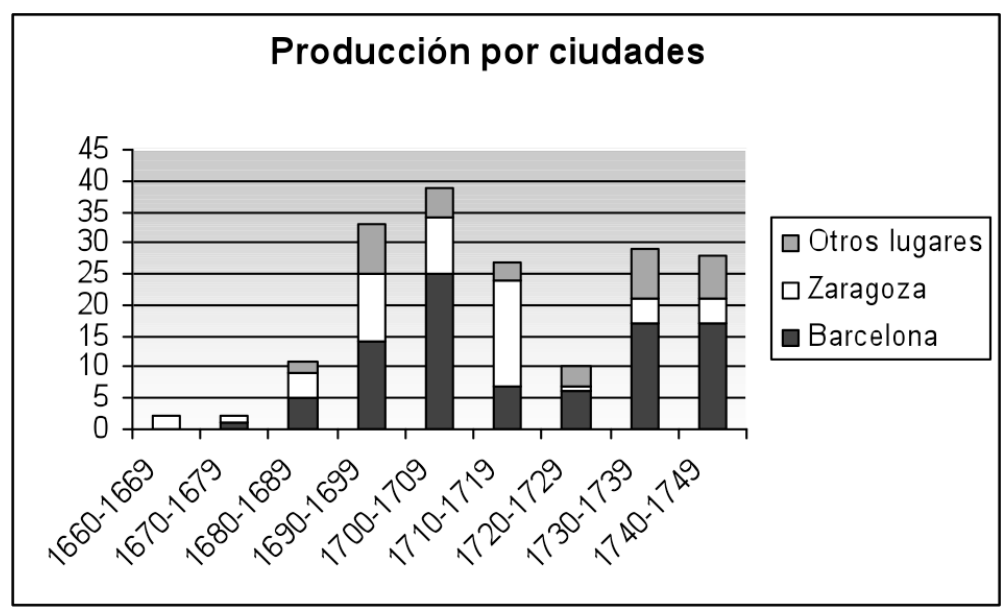


Tan acusada es la vinculación del fenómeno a ambas ciudades, que se puede hacer una lista de extensión razonable para el resto de centros: Tarazona, 1684; Madrid, 1684?, 1708, 1728, 1733; Manresa, 1690 y 1744; Valls, 1695, 1699, 1709, 1739; Valencia, 1695; Villafranca del Penedés, 1697, 1699 (dos pliegos) y 1702; Mataró, 1703; Córdoba, 1697?, 1709-29, 1714, 1730; Trasobares, 1713 ${ }^{14}$; Reus, 1717; Calatayud, 1721; Sevilla, 1730; Montblanc, 1730; Lérida, 1734; Seo d'Urgell, 1735; Tarragona, 1738; Tudela, 1743, 1745 (dos pliegos); Vic, 1745, 1748; Barbastro, 1746. El listado pone en evidencia que casi todas las poblaciones pertenecen al área de influencia cultural de Zaragoza o de Barcelona, y se observa que algunos pliegos para ceremonias en Manresa, Mataró, Reus, Seu d'Urgel y Valls se imprimieron en Barcelona; o los de Barbastro, Tudela, Calatayud o Trasobares procedían de imprentas en Zaragoza ${ }^{15}$.

Fuera de estas áreas geográficas, Madrid, Córdoba, Sevilla y Valencia tienen algunos pliegos de profesión, aunque son muy pocos, en particular considerando la importancia económica de esos centros, el alto número de conventos en todos ellos y la existencia de una larga tradición de pliegos navideños conventuales. El fenómeno del pliego de profesión se da en unas zonas bien delimitadas. Ambas ciudades del reino de Aragón comparten el entusiasmo por este subgénero, pero el gráfico comparativo demuestra que, entre ellas, Barcelona produjo un número significativamente más alto y que la evolución cuantitativa solo es parcialmente coincidente.

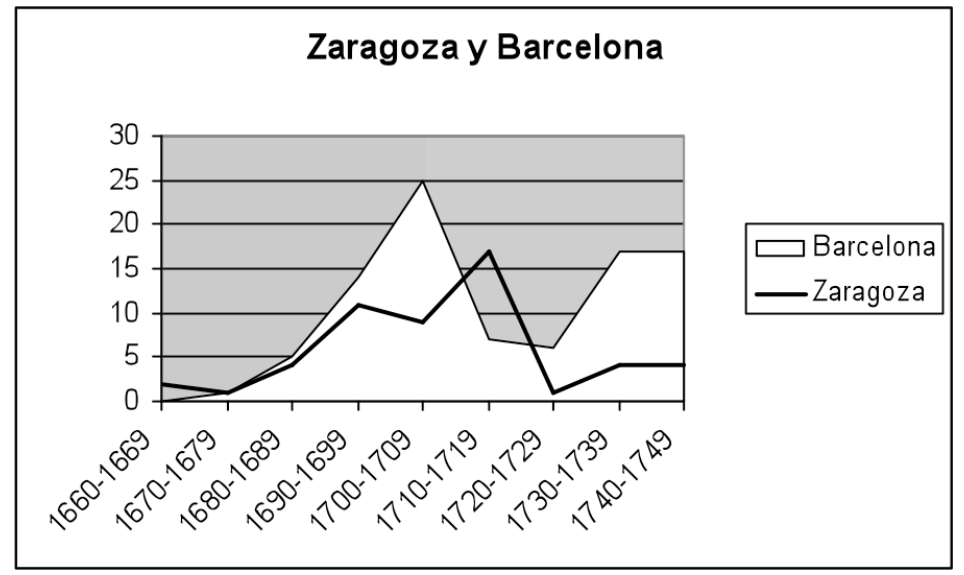

14. Recordemos que en esta localidad también se imprimió uno de los primeros pliegos del género en 1644.

15. El gráfico por lugares no refleja los de impresión, sino dónde se celebraron las ceremonias. 
El pico máximo de la ciudad condal se produce entre 1700-1709 y el de Zaragoza entre 1710-1719, si bien ambas comparten el nivel mínimo de producción en 1720-1729, aunque Zaragoza se recupera después débilmente, mientras que en Barcelona el fenómeno tomará la gran pujanza anterior.

Qué duda cabe que este panorama debe estar parcialmente sesgado por factores aleatorios de conservación de las piezas. Por ejemplo, el hecho de que uno de los volúmenes de The British Library proceda seguramente de Zaragoza (Marín, 2000) llevará a cierta sobrerrepresentación de impresos de esta ciudad, sin embargo la diferencia entre Barcelona, Zaragoza y el resto de lugares es tan grande que, a pesar de ese desvío, hay que aceptar que el uso de estos impresos en las ceremonias de toma de velo era un rasgo característico de los conventos de esas ciudades, mientras que resultaba raro en el resto. Pensemos que los pliegos navideños de las Descalzas reales de Madrid en la Biblioteca Nacional ofrecen series casi anuales de impresos, bien para la nochebuena, bien para la festividad de Reyes, pero no sucede lo mismo con las profesiones religiosas y en el caso de este monasterio era seguro que la celebración de estos actos se hacía con toda solemnidad y pompa, porque lo establecían las constituciones dadas por Juana de Austria en 1572, donde se dotaba especialmente una capilla musical propia de gran categoría, que luego fue ampliada por Felipe II (Sánchez Sicart, 2001: 35; Capdepón Verdú, 1997).

En este aspecto es relevante notar cómo el fenómeno no se vincula a ninguna orden religiosa en particular, ya que la mayor parte de ellas tenía conventos por todo el territorio peninsular y sobre todo en la corte. En Zaragoza imprimen estos pliegos los conventos de carmelitas descalzas, capuchinas (O. Santa Clara), Agustinas, Comendadoras de Jerusalén, Orden de San Bernardo, Compañía de María o Dominicas; y lo mismo se puede afirmar de Barcelona, donde son varias las órdenes instaladas en la ciudad que recurren a estos impresos celebrativos. Por tanto, parece existir un efecto de contagio por imitación que afecta al tejido urbano o a su área de influencia cultural, pero que no se propaga entre los conventos de una misma orden, a pesar de que éstos compartían la regla, el carisma y el costumario. Esta constatación permite sugerir que estas publicaciones tienen menos valor religioso que social, en tanto que sirven para distinguir a un convento y a una familia en su entorno urbano, lo que tiene un efecto emulador sobre el resto de la sociedad de una zona, en una competencia de prestigio; mientras que no afecta a otras áreas, donde la pugna entre linajes o instituciones no se realiza en los mismos términos. Apuntan en esta dirección algunos pliegos primerizos, donde la portada resalta el parentesco ilustre de la profesa: Francisca de Córdoba y Ribera es hija de los Marqueses de Priego 
(Córdoba, 1634), Josepha de Palafox y Cardona es hija de los Marqueses de Ariza (Zaragoza, 1665 y 1666), Mariana Antonia de la Concepción es hija del duque de Osuna y los reyes asistieron a la ceremonia (Madrid, 1684?). Recordemos asimismo que Bombi (2007: 159) subraya cómo el villancico requería unos medios para la interpretación que lo hacían muy apto para el despliegue social y que su uso en la capilla real reforzó su percepción como un género institucional para la expresión del poder.

\section{EL PLIEGO IMPRESO}

El pliego de profesión característico es un impreso humilde, en tamaño cuarto $^{16}$, casi siempre de 4 hojas con apenas adornos. Algunos tienen una vińeta xilográfica en la portada representando al santo tutelar de la orden (San Francisco, Santo Domingo, Santa Teresa...) o del convento más excepcionalmente $^{17}$ (santa Lucía, en el pliego zaragozano de 1693 vinculado al convento de ese nombre), siempre de factura muy tosca. No obstante, son más habituales las portadas exclusivamente tipográficas, que juegan con los tamaños de letra y con el texto enmarcado en una orla, que en algunos pliegos más elegantes también adorna las páginas interiores. El título es el eje de identificación de la pieza, porque consta de una serie de items informativos recurrentes, lo que demuestra que nos hallamos ante un modelo editorial: un sustantivo metaliterario que menciona el género poético del contenido, el nombre de la profesa, el convento en el que toma los votos y la fecha. Cada uno de estos elementos básicos de significación puede ir matizado en diversas formas: el nombre de la profesa a veces es solo el seglar, otras el religioso, en ocasiones ambos; también se puede señalar su parentesco con alguien relevante en la sociedad del momento, aunque el número de impresos dentro del total es inferior al $10 \%$. Sin embargo, parece significativo para explicar la existencia de algunos pliegos fuera del entorno zaragozano o barcelonés, ya que ese elemento de prestigio tiene la importancia suficiente como para ser reseñado en la portada, lo que subraya que esa circunstancia era de peso

16. Solo registro un pliego madrileño en tamaño folio: Letras que se cantaron en el convento de la Magdalena de esta Corte, en aplauso de la entrada de religiosa en él de Doña Maria Luisa de Várcena, a 16 de diziembre de 1728, s.l., si., s.a., 4 hs., BNE, VE- 1306- 97.

17. El siguiente pliego presenta en portada una vińeta de Santa Bárbara, solo explicable porque el nombre de la fundadora de la orden capuchina en España era Bárbara Serafina : Letras que se han de cantar en el Religiosísimo Convento de las Madres Capuchinas de la Ciudad de Zaragoça a la professión de sor Ysabel Maria Buil y Capapê, el dia 27 de Diziembre de 1696, Zaragoza: Herederos de Diego Dormer, s.a., BNE, VE -1189-33. 
en la celebración. Por ejemplo, el único pliego de Valencia es por la profesión de doña María Antonia García y Forés, a la que asiste el virrey, marqués de Castel Rodrigo (1695); de los tres madrileńos el primero es por la hija del duque de Osuna (1684) y el último, en 1733, por la hija de los señores don Félix Palacios y doña Manuela Sanz Bustillos. En Córdoba los pliegos de 1697?, 1709-29 y 1714 tienen relación con fray Francisco de Posadas ${ }^{18}$, en el primero porque él predicó el sermón de la ceremonia ${ }^{19}$, en los otros dos, porque las jóvenes habían sido bautizadas por él ${ }^{20}$. Posiblemente el origen de las piezas esté en la voluntad de las familias ilustres de distinguirse, ya que el pliego sería un elemento adicional del boato celebrativo que asemejaría una ceremonia privada a las institucionales, por eso los primeros conocidos son a hijas de familias ilustres que se citan en portada (no en Barcelona). A falta de una investigación histórica sobre cada caso es imposible conjeturar si otras profesas pertenecían a familias de la aristocracia o la nobleza, aunque estarían entre las clases pudientes, dado que el pliego sería un gasto más dentro del coste de acomodar a la hija, que incluía la dote para profesar como monja de velo negro y, por supuesto, los gastos de la ceremonia de profesión. Por otro lado, no olvidemos que en una determinada sociedad urbana de elite muy reducida, como la del período, no sería necesario explicitar el parentesco de una persona para deducirlo fácilmente de sus apellidos.

El nombre del convento suele ir acompañado de la identificación de la orden religiosa a la que pertenece, la ciudad y, alguna vez, se indica quién era la abadesa en ese momento. Este último dato aparece en ocho pliegos:

18. Teólogo dominico (Córdoba 1644-1713) de relevancia local, arzobispo de Cádiz, predicador en actos oficiales de la ciudad, barajado como posible confesor de Carlos II y autor de varias obras, entre ellas una biografía de sor Leonor María de Cristo (1699) y una Carta del esposo Christo a las religiosas sus esposas, que publicó por primera vez en sus obras póstumas, Córdoba, 1736-1739.

19. El pliego no tiene fecha (Catálogo 1992: no 53), sin embargo, existe un Sermon predicado en el convento de Iesus Crucificado ... en la solemne profession que hizo la Madre Soror Cathalina Iosepha de Iesus Maria, hija de ... don Diego de los Rios Cabrera de la Cerda y de doña Iosepha Maria de Cardenas y Angulo, Marqueses de la Villa de la Escalonia, Córdoba: Diego de Valverde y Leyca, 1697.

20. Letras que se cantaron a la profesion de sor Isabel Francisca Fernandez ahijada de bautismo del V. P. M. Fr. Francisco Possadas, y religiosa en su convento de Jesus crucificado, orden de S. Domingo de la ciudad de Cordova à dies y seis de Julio de mil setecientos y catorce, s.l., s.i., s.a. (Catálogo 1990: no 83) y Villancicos a la professión de la señora dña. Maria Ana Victoria, Francisca, Josepha de San Diego, nacio a diez de febrero, se baptizó a cinco de Marzo, fue su Compadre un Cavallero Soldado D. Diego de Novoa, y despues Hermano de Jesus, y Fundador del Hospital de Pozoblanco, el V. Hermano Diego de la Cruz presentole una Medalla de N. Señora del Rosario, y señor Santo Domingo, y una Cruz. Baptizóla el V. P. Presentado Fray Francisco Posadas, Córdoba: Acisclo Cortés, 1709-29 (Catálogo 1990: no 82). 
uno de Madrid, 1733, y los demás de Barcelona, siempre cuando se trata del monasterio de Monte Sión (1729, 1741, 1746 y 1749, 2 pliegos) o del Convento de Santa Isabel $(1736,1746)$, aunque no es la norma para ninguno de ellos. Casi todos los pliegos barceloneses y muchos de su área de influencia incluyen en la titulación el nombre de la capilla musical que canta en la ceremonia y el maestro que la dirigió: esta información no se considera relevante en los pliegos zaragozanos, donde nunca aparece citado. Los maestros se repiten por períodos cronológicos y también las capillas, entre las cuales las del Palau y la de la catedral son las más citadas. Su presencia daba relieve y categoría al acto y nos indica la importancia que el elemento musical, la interpretación, tenía para el entorno barcelonés. Eso no significa que en Zaragoza fueran las monjas quienes cantaran en la ceremonia, por más que hubiera en general profesas con conocimientos musicales que las habilitaban para un desempeño profesional (Olarte, 1993), lo que era uno de los escasos medios para quedar eximida de pagar la dote. Pero la diferencia entre unos conventos y otros era notable, así por un lado existen grandes alabanzas a ciertos conventos por su calidad musical (por ejemplo, el Real convento de San Clemente de Sevilla), mientras otros son denostados porque llegan a provocar la risa del público (Sanhuesa Fonseca, 2004: 176177). En ambos casos para las ceremonias especiales se podían contratar ministriles y cantores que reforzaran el coro o que mejoraran su calidad, como se hacía en las Descalzas.

Posiblemente el aspecto más llamativo de los títulos es el que afecta al término metaliterario con que suele comenzar. Los pliegos impresos en Barcelona empiezan de forma sistemática por el sintagma «villancicos que se cantaron...", excepto en nueve casos, casi todos ellos entre 1733-1749, donde la titulación recurre a términos muchos más elaborados, como si el habitual villancicos hubiera sufrido un desgaste ${ }^{21}$. En todo caso siempre se emplea el verbo en pasado (cantó o similares), que supone una difusión del pliego posterior a la ceremonia, según observa García de Enterría (1989: 148-149). La misma sencillez en la terminología metaliteraria está presente, por lo general, en los pocos pliegos fuera de la zona de influencia barcelonesa

21. Festivas y sacras consonancias en la profession y velo..., 1713; Epithalamio sacro que..., 1733; La muger fuerte: oratorio que se cantó en...; El Alcázar de David mysticamente renovado en..., 1735 ; La esposa santa en su sacro desposorio. Poema sagrado, que en la profesión..., 1746; La mas sabia leccion en la Escuela de María: drama sacro alegórico que en la profession..., 1746: Quién hallará muger fuerte?: harmoniosa poesía... 1749; Letras de los villancicos que se han de cantar en..., 1749; La religión y constancia en la nave de Pedro: alegórico drama que en la profession de..., 1749; Villancicos que en alusión a la historia de las Santas onze mil Virgenes..., 1749 . 
o zaragozana. Sevilla, Córdoba, Valencia o Madrid emplean preferentemente el término «letras» y alguna vez «villancicos» ${ }^{22}$.

Zaragoza en este aspecto sigue sus propios criterios y practica un barroquismo imaginativo que va in crescendo, posiblemente en busca de una sorpresa cada vez más difícil de obtener, por lo que se pueden señalar modas y momentos. En los primeros pliegos, entre 1683 y 1701 aproximadamente, el título que predomina es Letras que se han de cantar. El abandono de ese término podría estar causado por un cambio en el tipo de poemas, ya que la letra tenía carácter principalmente narrativo, incluso cuando tomaba la forma de un diálogo (Bombi 2007: 159). Sin embargo, no se aprecian diferencias relevantes con pliegos que tienen otros títulos y donde hay villancicos, lo que no es de extrañar si recordarmos que la crítica ha señalado reiteradamente la indefinición en los límites genéricos entre letras, villancicos y sus diversas formas ${ }^{23}$. Inicialmente los títulos zaragozanos emplean dos veces «A la profesión....» (1678 y 1688), sintagma que no aparece después ${ }^{24}$. Pero esa y otras titulaciones sencillas desaparecen en torno a 1700. Dado que desde el punto de vista de la iglesia la profesión religiosa se ha considerado como un matrimonio con Dios, el término epitalamio, que se empleaba con frecuencia en la celebración impresa de bodas profanas, se extiende a los pliegos de tomas de velo. De hecho uno de los pliegos más primitivos (Trasobares, 1644) emplea precisamente Epitalamio en su título ${ }^{25}$. Entre 1682 y 1715 el término epitalamio junto a adjetivos como «sagrado / sacro / heroico religioso / acorde / heroico / armónico», etc, aparece en once títulos. En algunos casos es sustituido por un término aún más culto, también del campo semático del matrimonio, como es himeneo, que figura en 1704, 1705, 1713 (dos pliegos) y 1745. Junto al campo semántico del matrimonio, tiene mucha aceptación el de 'canto laudatorio': panegírico, himnos, cánticos, aclamaciones. No obstante, solo algún ejemplo particular puede dar idea de la

22. Solo en el caso de Madrid, 1733 hay una titulación más elaborada: Lyrico clarin [...] en aplauso de la profession de doña Maria Josepha Manuela...

23. Son muchos los estudios sobre el género, pero se puede consultar con provecho un estado de la cuestión en Knighton y Torrente (2007: 1-14). Entre otros han sido de utilidad en este artículo los de Sánchez Romeralo (1969), Laird (1997), Tenorio (1999) y el tomo de actas coordinado por Virgili, Vega y Caballero (1997).

24. Precisamente el título permite proponer la datación por esos años del siguiente pliego: A la profesión de fe de sor Teresa Etulayn y Muro: religiosa de Santa Fe, .s. l.: s.n., s.a (Madrid, BNE, V.E./1184-13).

25. La contaminación o influencia mutua entre el pliego celebrativo de la boda profana y de la toma de velo habrá de ser tenida en cuenta al estudiar con más detalle estos pliegos. Recuérdese el Epitalamio a las felicíssimas bodas del Rey Nuestro Señor, que estudia Ma Carmen Marín Pina en este volumen. 
capacidad creativa de estos autores, en un adorno equiparable al altar barroco: Sagrado panegírico en métricas aclamaciones a la professión de la madre Josefa de S. Teresa, en el siglo D. Josefa Mathas del Rio y Villalba, en el religiosissimo convento de las madres carmelitas descalzas de San Josef de Zaragoça ${ }^{26}$; Sonoros acordes cánticos en el más divino hymeneo, florilegio sagrado, que se ofrece a la señora sor Thomasa Ortiz y Rabal, en el dia que celebra augustas bodas con su divino esposo Christo, en el convento de la Encarnación ${ }^{27}$; Vuelo mystico, viaje enamorado, ciencia de perfectos, camino dichoso, retiro admirable con que la Madre... se previene para el feliz desposorio con su amante Jesús ${ }^{28}$.

Este estilo impregna otros pliegos de la zona de influencia cultural zaragozana, según se observa en el siguiente título de un pliego de Tudela ${ }^{29}$ : Hymnos acordes, cánticos festivos, sonoras aclamaciones, con que se celebra el dichoso arribo, y el feliz ingresso de las muy ilustres señoras... Se trata de otro rasgo que corrobora cómo las características del subgénero vienen determinadas por el ámbito geográfico, que debe considerarse un aspecto relevante en el estudio de estos pliegos, al menos mientras no se realice un análisis profundo de sus contenidos.

Este rasgo estético tan acusado de los pliegos del área zaragozana se acompaña de otra diferencia sistemática en su relación temporal con la ceremonia. Los primeros impresos usan el tiempo pasado para indicar que el texto se entrega después de la celebración, pero en el decenio 1690-1700 cambia la tendencia y desde 1699 solo uno de 1712 usa el pasado, ya que el resto marca claramente el futuro o emplea un presente que parece estar usado como futuro: "que se han de cantar», "ha de servir de harmonía», "que se ofrece a... siendo la solemnidad el día...». En un caso el día queda en blanco en la portada, seguramente a falta de decidir la fecha definitiva o de enviar esta información a la imprenta: Harmónico, sacro, dulce, epitalamio a la profesion de la señora doña Maria Teresa Miranda, en el Real Monasterio de Santa Lucia, el dia... de enero del año $1715^{30}$. La diferencia sistemática entre el pasado cantó en los títulos de Barcelona y el futuro en el área zaragozana sugiere que entre ambas ciudades había usos distintos y que en Zaragoza se

26. Zaragoza: Jayme Magallón (?), 1701 (Madrid, BNE, VE- 1327/16). Hay otro pliego de título casi idéntico y también para una profesión en el convento de Carmelitas Descalzas de Zaragoza (Madrid, BNE, VE1201-21).

27. Zaragoza: Pedro Carreras, 1704 (Madrid, BNE, VE 1191/ 17).

28. Zaragoza: Herederos de Manuel Román (Madrid, BNE, VE-1303-29).

29. El pliego está impreso en Zaragoza, Joseph Fort, 1743? (Madrid, BNE, VE-1307-17; y Nueva York, Public Library, Spencer Coll. Span. 1733 96-527/45).

30. Zaragoza: Diego Larumbe, 1715 (Catálogo 1990: n 585). 
debía difundir antes de la ceremonia de profesión, quizá con una función de reclamo o convocatoria. Algunos de esos pliegos parecen ofrecer todos los datos para presentarse en el acto, como si de una invitación se tratara, por ejemplo: Sagrado cortejo, diversión obsequiosa, que en festivos cultos explica los aplausos, y felicidades que en el Carmelo se merece la señora doña Luisa Adán de Forz y Gayán. En el divino hymeneo en que a Dios se consagra en el Convento de la Encarnación, del Orden de Nuestra Señora del Carmen de la Ciudad de Zaragoza. El día 24 de Agosto del año $1713^{31}$. Quizá la diferencia de uso que se daba entre unos y otros lugares y tipo de pliegos explique la falta de acuerdo crítico sobre el proceso de difusión, que Garbayo Montabes (2005: 64-65) resume para concluir en que es un tema aún poco estudiado, si bien se inclina por rechazar su distribución indiscriminada entre el público para señalar que actuaban como un recuerdo.

\section{Ceremonia y pliego}

La ceremonia de toma de velo o de profesión revestía gran importancia no solo para la monja, que era el centro del acto, sino para su entorno social. En ese acto, que tenía una parte pública, convento y familia pretendían hacer notar su rango, así compartían el mismo interés en exhibir su prestigio parejo a través de: elementos materiales, que se podrían cifrar en la riqueza y sus apariencias; elementos religiosos, que constituyen un patrimonio simbólico o preeminencia jerárquica de una orden o convento frente a otros; y elementos organizativos, que pertenecían propiamente al acto y a la capacidad de solemnizarlo en sus diferentes momentos. En 1683 la duquesa de Veraguas envía al convento de Capuchinas de Murcia 500 ducados para la celebración de la toma de velo de sor Juana María de la Peña, que había sido su dama favorita. Como no puede asistir, serán padrinos en su nombre el Corregidor de Murcia y su esposa. La ceremonia, a la que está invitada toda la nobleza local, incluye «aparato de música, fuegos artificiales, sermón, missa solemne, con las demás celebridades y festejos que cupiesen. La capilla de la cathedral echó este día todo el lleno de su habilidad en composiciones de buen gusto, sonoros y acordes instrumentos y letras devotas y discretas dirigidas a las nuevas bodas, desposorios de la nueva professa», Zevallos (1736: I, p. 401). En otros casos no debía haber tantos medios y las ceremonias tenían un carácter más íntimo: «Trova de la cantata $O$ cielos para cuándo los rayos? que la cantó dońa Teresa Ortí y Bonavida, niña de 9 años, en la ingresión de su

31. Zaragoza: s.n, 1713 (Londres, British Library, 1973.k.22 (13); Madrid, BNE VE 533-9). 
prima doña María Lorenzo Bonavida y Tallada en el religiosísimo convento de S. Cristóbal de Valencia día 12 de noviembre año 1712» (Bombi, 2007: 182). En cualquier caso la música tenía un papel primordial, en tanto que era un aspecto muy apreciado del boato organizativo y del éxito del acto, hasta el punto de que determinaba la brillantez de la ceremonia y era un elemento de representación que marcaba la diferencia entre las diversas instituciones (Fernandes 1997-98: 71).

El desarrollo del acto tenía prácticas peculiares en cada orden e incluso distintivas entre conventos, sin embargo sus elementos esenciales eran comunes, en particular en lo que atańe a las partes que componen el acto y a su simbolismo. No conocemos detalles de la mayoría de estos ceremoniales, en especial referidos a las épocas que aquí nos interesan, pero nos proporcionan una idea algunos que se remontan con seguridad a principios del siglo XVII, como los de las Descalzas Reales y el Monasterio de la Encarnación de Madrid, estudiados por Sánchez (1997) ${ }^{32}$. La toma de velo significaba el paso definitivo de la novicia de la vida seglar a la religiosa, después de al menos un año de formación desde que había solicitado la admisión al convento, se le había cortado el pelo y había vestido el hábito. Parte de las ceremonias tenían lugar en el interior de la clausura y a ellas solo asistían las religiosas. Podían incluir una procesión, una entrega de las constituciones de la orden, un sermón admonitorio de la priora y algún otro rito, según el ceremonial propio. La segunda parte de estos actos tenía lugar en la iglesia y consistía esencialmente en responder al interrogatorio del prelado, lo que constituía la aceptación formal de los votos de castidad, pobreza y obediencia, además del encierro perpetuo en la clausura. Una vez formulados los votos, la nueva monja recibía el velo negro, de manos de la priora, la maestra de novicias o el preste, velo que previamente había sido bendecido. Esta entrega de símbolos incluía también una corona con flores. Entonces podía hacerse un toque de difuntos, símbolo de que estaba muerta al mundo, y una invocación al Espíritu Santo y al santo patrón de la orden, seguida de una admonición para que siguiera estrictamente la regla y la obediencia a su prelada.

32. Agradezco a Leticia su generosidad al proporcionarme información sobre este aspecto, enviarme trabajos aún en prensa e imágenes, como la del cuadro de Antonio Pereda, que presenta a sor Ana Margarita de Austria, hija natural de Felipe IV, profesando en el convento de la Encarnación (se puede ver una imagen en la web [consultada noviembre, 2010]. Disponible en: http://www.oronoz.com/paginas/leefoto.php? referencia $=\% 20 \% 20$ 3251\&usuario=). Otras referencias a estas ceremonias en Gembero Ustárroz (2007: 329-30), Fernandes (1997-98: 72 y ss.) y Monson (1995: 182-198), éste sobre las celebraciones en el convento boloñés de Santa Cristina della Fondazza, famoso por su música. 
Los momentos culminantes de esta ceremonia debían ir subrayados por la música, como sucedía en toda la liturgia católica, si bien en los casos de especial solemnidad ésta adquiría también más importancia. Lamentablemente los ceremoniales se refieren a la música oficial de la liturgia latina, pero no indican dónde o cómo se insertaba la música vernácula, que es la que recogen los villancicos, entendiendo con este término, para la época que nos ocupa, toda composición autónoma religiosa en lengua vulgar interpretada en un contexto religioso, sin restringirnos a un sentido genéricamente estricto $^{33}$. Sin embargo, en muchos de los poemas de los pliegos se hacen referencias a los objetos simbólicos o a la muerte al mundo de la profesa, etc. por lo que sería esperable que se interpretaran inmediatamente antes o después del momento en que tal acto se estaba produciendo ${ }^{34}$. Entre los poemas consultados no se dan indicaciones sobre esta cuestión performativa, posiblemente porque era innecesaria para el público y menos aún para los cantores. En un pliego madrileño a la profesión de una hija del Duque de Osuna en las Carmelitas descalzas se dice «Estas seguidillas se cantaron antes de alçar el Santíssimo Sacramento» ${ }^{35}$ y Fernandes (1997-98: p. 73) recoge documentación de que las palabras del voto en Portugal, al menos en algunas órdenes, era cantado por la profesa, aunque seguramente con una monodia ${ }^{36}$. Sin duda existían diversas posibilidades, por eso los pliegos no contienen siquiera un número fijo de composiciones, si bien el número mínimo (los llamados juegos ${ }^{37}$ ) parece ser de tres, aunque los autores que

33. Definición del término tomada de Torrente, si bien a través del resumen de toda la cuestión genérica en torno a villancico que presenta Bombi (2007: 149-150). Ni siquiera Aguirre (2004: 304-306), que ha tratado este aspecto con mayor detenimiento y ha revisado abundante documentación, señala con exactitud dónde se podían insertar los villancicos.

34. Sería necesario un estudio pormenorizado del contenido de estos juegos de villancicos, distribuidos por órdenes y conventos para establecer un posible patrón de su ubicación precisa dentro de las ceremonias.

35. Fechado hacia 1684. El pliego va firmado al fin «Por un músico de la capilla real» (Catálogo, 1992: $\left.\mathrm{n}^{\circ} 127\right)$.

36. Pudiera responder a esta costumbre el romance de Violante do Ceo «Soliloquio que cantou a Authora no dia em que havia fazer sua profisao, ao levantar a Deos na Missa solemne» (Parnaso lusitano: 273-275). Bombi (2007: 182) recoge una rúbrica que explica: «A la profesión de la señora doña maría Lorenza Pallás y Pérez de Sarrió en la Zaidía, día 24 de abril 1715... Para cantar en la misa...» Comenta la autora: «In other cases, found in E-Vsm 6366, the moments specified for the performance of sung texts are after the Epistle, and before, during and after communion». Su fuente da indicaciones de que el uso de un voto cantado podría ser ocasional: «Al velo de una religiosa del convento de las Magdalenas, hija de Alzira, cantora de gran habilidad y perfección. Coplas para que ella misma las cantase en su nombre» (Bombi, 2007:181).

37. Por juego entiendo, como en el caso de los pliegos navideńos, el conjunto de villancicos creados para una determinada ocasión en la que se interpretarán de forma sucesiva. Esta es 
las recopilan en sus cancioneros suelen componer un máximo de dos a un mismo evento. Sin conocer qué factores influyen (la situación económica y relevancia de la familia, las exigencias del ceremonial, el día de la celebración, los medios para la interpretación en el propio convento o la contratación de intérpretes, como se detalla en Barcelona, con qué música se interpretaban...) no es posible establecer por ahora sus pautas funcionales.

\section{Textos poÉticos}

La ceremonia de profesión proporciona todo el universo simbólico sobre el que desarrollar los temas poéticos de los villancicos o piezas cantadas. No hay que olvidar que los textos no son más que una parte del artefacto complejo en el que la música es lo verdaderamente importante. El villancico desde su origen es un género para ser cantado, compuesto esencialmente por dos partes: una primera parte, con sabor y estilo populares y de expresión concisa, que se denomina estribillo; y una segunda parte formada por un número variable de coplas, que en cierto modo desarrollan o glosan el contenido del estribillo. Las formas métricas que puede adoptar son de una flexibilidad extrema, tanto en el número de versos del estribillo (que puede ir desde dos versos a una gran extensión) como en el número de coplas, su versificación y su rima, ya que lo esencial del texto es la música:

Al músico le importa muy poco o nada el problema del esquema métrico literario, porque al fin y al cabo los musicará de acuerdo con las leyes específicas de la construcción musical (que está lejos de concordar con las estructuras poéticas y con los intereses de los literatos) y manejará la estructura métrica a su antojo y conveniencia. (Climent, 1997: 24)

Sin embargo, ninguno de los pliegos consultados incluye notación musical, y solo en un caso se hace referencia a la tonada que se debe emplear para el canto ${ }^{38}$. Lo que queda a nuestro alcance son los textos, cuyo contenido

una característica definitoria de los pliegos de profesión, frente a otras fuentes que no ofrecen todas las piezas de un acto.

38. Elogios a la professión de mi señora doña Ana Garcés, en el Real Convento de Religiosas Bernardas de Santa Lucía, día de la Exaltación de la Cruz, este año de 1694, s.l. [¿Zaragoza?] (Madrid, BNE, VE 1197/11 ; Londres, British Library, 1073.k.22 (66). La última pieza del pliego tiene la siguiente rúbrica: «Troba por el tono de la comedia de Tetis y Peleo, que empieza no sino yo, al certamen Príncipe Augusto. Coloquio entre el Mundo y la Religión». Estas breves calas en el contenido de los pliegos se basan en una pequeña parte del total (en torno al $20 \%$ ) y solo tienen una pretensión orientativa. 
demuestra que fueron compuestos o adaptados expresamente para cada ocasión recurriendo a un nutrido repertorio de recursos versificatorios manejados en el subgénero y que dan expresión, como en el caso del villancico navideńo, a los símbolos subyacentes en una larga tradición litúrgica. El más importante de todos, el que aglutina la mayor parte de los elementos alegóricos, es el matrimonio, un material rico en posibilidades narrativas del que el poeta elige los motivos para prestar variedad a los textos y crea un conjunto de alegorías superponiendo ambas realidades, como señala Alain Bègue (Torrente, p. 281). La virginidad de la religiosa consagrada a Dios está conceptuada como un desposorio espiritual en todos sus extremos: la ceremonia emplea los mismos objetos simbólicos (el velo, la corona) y las relaciones entre los contrayentes se expresan en términos semejantes a los que actúan para las relaciones humanas, en una trasposición total del plano humano al divino (Metz, 1954; Menéndez Peláez, 1980: 17-49).

El tema de las bodas consiguió prestar una gran variedad a los villancicos de profesión a partir de la trasposición a lo divino de cualquier aspecto de la realidad humana: la historia del noviazgo (puede incluir los celos, la fuga, lugares de cita), la celebración del contrato y las arras, las prendas y virtudes del novio o de la novia, la dote, las obligaciones de la futura desposada, etc. Toda esta casuística tópica, arrastrada por la tradición del villancico, se presenta a menudo bajo una modulación pastoril (los zagales, el galán de la pastora) o como un relato de boda. En el pliego cordobés a la profesión de Catalina Josefa de Jesús María, el galán ronda embozado la "puerta de los deseos de Catalina», silba y ella le abre el balcón de sus ansias, le arroja la escala, entra «en la sala del pecho / y en el retrete del alma / le dio palabra de esposo"; finalmente eligen por padrinos a José y María ${ }^{39}$. Entre estos motivos llama la atención el de los celos entre dos pretendientes, que pueden ser Cristo y el santo fundador de la orden. Por ejemplo, en Zaragoza 1678 "Christo y Francisco la quieren / para esposa; y en su orden / uno solo se consiente / mas haga lo que le importe. / Cásese bien que si un Dios / oy por esposa la escoge / la zelará un serafín...» ${ }^{40}$; y Zaragoza 1688: "Christo y Domingo la quieren / para esposa, pero ignora / pueda aver entre estos zelos / porque es de los dos la boda ${ }^{41}$. La alegoría pastoril es menos frecuente

39. Letras que se cantaron en la solemne profesión que hizo la madre soror Cathalina Iosepha de Iesus Maria en el convento de Iesus Crucificado, Orden de Santo Domingo, s.d., (Catálogo 1992: $\left.\mathrm{n}^{\circ} 53\right)$, ejemplar falto de portada.

40. A la professión de doña Josepha Teodora Montaner y de las Foyas, en el Convento de Santa Catalina de Zaragoza (Madrid, BNE, VE- 1184/15).

41. A la professión de la señora sor Teresa Apolonia Miranda religiosa en el convento de la Virgen, y mártir santa Inés, s.d. (Madrid, BNE VE-1184/ 14). 
en los pliegos de los decenios 1730-40 y se alterna con la imagen clásica de la esposa del cantar de los cantares, que a su vez estiliza la alegoría pastoril reduciendo los rasgos de lo rústico.

Junto al matrimonio, es frecuente la alegoría del jardín: la profesa es una azucena que se refugia en el pensil de cierta orden (el convento), donde otras flores admiran sus virtudes e intentan emularla, aunque no pueden. «La flor más hermosa / se exala a pureza / y por ser violeta humilde / buscó el pensil de Teresa... [...] En el pensil de el Carmelo / cándida pura azucena...» ${ }^{42}$; en la profesión de María Antonia Garcés las flores del Turia compiten con sus ondas en un certamen por ver quién sirve mejor a la profesa, a quien finalmente todas copian ${ }^{43}$. La mención a las flores da pie (y no podía faltar) a los tópicos del carpe diem y el desengaño, en particular subrayando la juventud de la novicia y su capacidad para dejar el mundo antes siquiera de haber podido sufrir su desengaño, lo que se alaba como gran sabiduría. Las aves, como era de esperar, son elementos metafóricos frecuentes en las alegorías. La profesa es similar a un águila que sube a los cielos, a una humilde paloma inocente e incluso a un fénix que renace a nueva vida. Mucha de esta simbología es recurrente, por ejemplo la imagen en que se contraponen el cedro y la flor o la planta humilde, que encontramos en algunos pliegos de la orden carmelita y que quizá no sea un efecto de imitación poética sino parte del acerbo simbólico de la orden, que los poetas conocen y trasladan a sus textos. Debemos recordar que el pliego, si bien se genera en torno a un acto privado y a una persona concreta, sirve a las estrategias de representación de la orden y forma parte de sus activos simbólicos y de su prestigio, con los que intenta superar y diferenciarse de otros conventos y órdenes a los ojos de la comunidad en la que se asienta. Por ello los poetas necesitan conocer esos elementos representativos que emplearán en sus textos y con los que jugarán léxica y metafóricamente: santo Domingo y el perro o la antorcha, San Francisco como serafín humano, la compañía de María en su función docente, etc. Se trata de imágenes y metáforas de larga vida, porque aparecen en pliegos a lo largo de todo el período analizado.

La monja llega al matrimonio sacro al vencer a los enemigos seculares del hombre, así entre los motivos puede estar presente el de la lucha, la batalla o la disputa entre el bien y el mal, que en algunos (pocos) casos se despliega

42. Villancicos que se cantaron en la professión de la madre Mariana Antonia de la Concepción..., Madrid, s.a. [1684?] (Madrid, BNE, R-34989/31).

43. Letras y villancicos de dos ingenios que se cantaron en el muy ilusre y real convento [...] de la Zaydia en 22 de agosto año 1695 (Valencia, Biblioteca Universitaria BH Var. 209 (09). 
en forma de diálogo entre los enemigos ${ }^{44}$. En un ejemplo el estribillo tiene forma de diálogo entre el infierno y el mundo, que se piden ayuda mutua para que la Marquesa no siga adelante con su decisión de profesar en el carmelo descalzo ${ }^{45}$. Son formas dialógicas que lindan con lo dramático, cuya tradición es larga en el villancico. Esta presentación, no obstante, es menos habitual que la del resultado, es decir, la ceremonia de profesión como un triunfo del alma que se dirige al cielo y cuya felicidad se celebra.

Quizá el rasgo más característico de los pliegos de profesión es la cita del nombre de la profesa en alguno de los villancicos. En su forma más sencilla y frecuente se trata solo de mencionarlo una o varias veces y no impedía la "trova», es decir, la modificación parcial de un texto para su reutilización, un proceso constante dada la demanda de materiales a lo largo del año para muchas instituciones y durante muchos años. Sor Inés Párraga escribe a Miguel Gómez Camargo en 1661: «El que estaba trobado para la profesión es mui sazonado i por tener en este conbento dentro de dos meses otra que se nombra también Teresa, suplico a Vmd. me la aga de imbiarme la troba de las coplas, que el estribo bien se entiende» (Aguirre, 2004: 307). Esta sencillez puede complicarse levemente con algunos juegos léxicos sobre el significante o el significado del nombre y/o apellido, dificultando en ese caso la trova. Es un calambur simple el de Gertrudis Arbolí y Ros, destacado en el impreso por las mayúsculas («donde aunque al mundo mueras / ARBOL -Y vida hallaràs... Y en él lo que ROS-as visto») ${ }^{46}$; o el de Ana Subirana y Juliol («más pareze SUBIR-ANA / oy que se humilla hasta el suelo») ${ }^{47}$. El uso reiterado del término CAMPOS, destacado en mayúsculas, en el pliego a la profesión de María Michaela Campos ${ }^{48}$, el MURO de Teresa Muro

44. El ejemplo más elaborado está en Elogios a la professión de mi señora doña Ana Garcés, en el Real Convento de Religiosas Bernardas de Santa Lucia, día de la Exaltación de la Cruz, este año de 1694 (Madrid, BNE VE 1197/11 ; Londres, British L 1073.k.22 /66), que contiene una «Troba por el tono de la comedia de Tetis y Peleo, que empieza no sino yo, al certamen Príncipe Augusto. Coloquio entre el Mundo y la Religión».

45. s.l. [¿ंMadrid?], s.n., s.a. [h. 1690?] (Madrid, BNE, R-34989/12).

46. La esposa santa en su sacro desposorio. Poema sagrado, que en la profesión, y velo de la señora sor Getrudis (sic) Arboli, y Ros, en el Real Monasterio de Monte-Syon de Religiosas del Patriarcha Santo Domingo de Barcelona, siendo priora la muy reverencida madre sor Francisca Vilana, Perlas, y Fabregas: Dia 20. de Junio 1746. Cantò la capilla de Santa Maria del Mar, siendo su Maestro el Reverenci Pablo Monserràt Presbytero (Catálogo, 1990: .n 1136)

47. Villancicos que se cantaron a la profession, y velo negro de la hermana Ana Subirana y Juliol Religiosa de la Compañia de Nuestra Señora de la Enseñança de Barcelona. Cantoles la Capilla de la Santa Iglesia de Nuestra Señora del Palau de Barcelona, siendo su Maestro el Licenciado Felipe Olivellas, en 12 de Junio 1695, Barcelona: Imprenta de Martin Gelabert, 1695 (Catálogo, 1992: no 13).

48. Acordes sagrados hymnos que se han de cantar en el Real Convento de Santa Inés, del Orden 


\section{CANTOS AL SACRO EPITALAMIO}

Etulayn $^{49}$ o los parónimos "pues toda es admiraciones / hasta el nombre de MIRANDA» ${ }^{50}$. En casos más elaborados esta adaptación ad personam puede consistir en la referencia a las circunstancias biográficas de la profesa. Por ejemplo, Maria Ignacia Azlor procede de México: «De México sale y vale / según sus dotes se tasan / más que muchos mexicanos / esta sola mexicana» ${ }^{51}$. Contesina Gilbert entró en el convento a los once años: «De onze años fue a su morada / y queriendo ser en ella / oveja del buen pastor / fue con sus onze de oveja» y en otro villancico: «En tus tiernos primeros abriles / pompas vanas supiste vencer/..» ${ }^{52}$.

Predicadores. En el feliz Mystico desposorio de la Señora Doña Maria Michaela Campos y García con su soberano esposo Iesus. El día 3 de octubre de este año 1718, Zaragoza: Francisco Revilla, s.a. (Catálogo, 1990: no 590).

49. A la profesión de fe de sor Teresa Etulayn y Muro: religiosa de Santa Fe, s.l., s.n., s.a. (Madrid, BNE VE 1184/ 13): «Muro es que Dios yedra abraça/ y aunque el muro de la yedra/ en el lazo se arruina/ este en su unión se sustenta...»

50. A la professión de la señora sor Teresa Apolonia Miranda religiosa en el convento de la Virgen, y mártir santa Inés, s.l., s.n., s.a. (Madrid, BNE VE-1184/ 14). La paronimia Mirandal admira es lugar común, según vemos en otro pliego («Pues Miranda es, en frasse concertada,/ la que merece ser siempre admirada»), Letras para la profession de la señora doña Petronila Rubi de Celis y Faxardo, dama que fue de la Reyna Madre nuestra señora, y despues casada con el Marques de Miranda de Aura Don Pedro Regalado de Porres y Toledo, Gentilhombre de la Camara de su Magestad, de su Consejo de Hazienda, y primer Cavallerizo de la Reyna nnuestra señora, Éc. Y aviendo enviudado de este Cavallero, con admirable desengaño se entro Carmelita Descalça en el Convento de la Baronesa en Madrid, dexando su casa, y conveniencias, y haziendo más heroico sacrificio de apartarse de una hermana, à quien estimava, como merecen las superiores circunstancias que concurren en su persona, Madrid, s.a. (Madrid, BNE, R-34989/12).

51. Hymnos acordes, Cánticos festivos, sonoras Aclamaciones, con que se celebra el dichoso arribo, y el feliz Ingresso de las Muy Ilustres Señoras Doña María Ignacia Azlor y Echeverz, y D. Anna de Torres y Quadrado en el Religiosissimo, y Exemplar Convento de la Compañia de María Santissima de las Señoras de la Enseñanza de la muy Noble, Antigua, y Leal Ciudad de Tudela. El día 2. de Febrero, año de 1743, Zaragoza: Por Joseph Fort, Impressor, s.a. (Madrid: BNE, VE 1307/ 17 ; Nueva York, Public Library, Spencer Coll. Span. 1733 96-527 /45). Dos años después celebra su profesión el Ramillete harmónico que en el ameno, sagrado y fructuosissimo pensil de la Compañia de Maria Santissima forma el regocijo, entretege el pasmo, y presenta el respeto a las ilustres señoras Doña María Ignacia Azlor y Echeverz y D. Ana de Torres y Quadrado con el feliz motivo de celebrar su profession... y mistico desposorio con el Rey de las Almas Jesu Christo en el... Convento de las Señoras de la Enseñanza de... Tudela, el día 2 de febrero año de 1745, Zaragoza : por Joseph Fort..., [1745?] (Catálogo, 1990: $\left.\mathrm{n}^{\circ} 1346\right)$.

52. Heroyco epitalamio, cantico armonioso, con que se celebra el sagrado mistico desposorio de la señora doña Contesina Gilbert de Balanzategui, Fernandez de Heredia, Magallon, y Peña, Con el Soberano Esposo Christo. En el Religiosissimo Convento de Jerusalèn, del Orden del Serafico Padre San Francisco, de la Ciudad de Zaragoça. En el dia 4 de Marzo de el año 1714, Zaragoza: Francisco Revilla, en la Calle de San Lorenço, s.a. (Madrid, BNE, VE 1441/10). 
Aunque en algunos momentos se encuentre poesía digna de tal nombre, la calidad literaria no es el fuerte de estos pliegos, como acertadamente refleja la apotegma 456 de Juan Rufo (1972: 162):

Estando ciertos amigos comunicando entre sí algunas poesías, recitó uno de ellos un villancico que había hecho al velo de una monja, que decía así:

\section{Hoy una prudente esposa muy bien se descasa y casa, pues del mundo se descasa y con Cristo se desposa}

Acabado de recitar, le preguntó qué sentía de aquella copla. Respondió que parecía pleito ante el vicario.

La escritura femenina tuvo en los conventos uno de sus reductos más importantes, ya que era prácticamente el único entorno en el que las mujeres la ejercían de modo "profesional" y por tanto necesario en su vida cotidiana. Sin embargo, no se puede considerar aisladamente, sino parte de un entramado cultural complejo en el que los ejes producción / recepción e individual / colectiva ofrecen muchas combinaciones. Dentro de ellas no es menos interesante atender al mecenazgo y el encargo, cuyos resultados no eran creación de las monjas, pero respondían a sus intereses y eran parte de sus medios de presencia o proyección sobre el entorno del que dependían. La clausura estricta impuesta en el Concilio de Trento privó a las monjas de interactuar personalmente con el tejido urbano al que pertenecían y del que dependían para su supervivencia, bien en forma de limosnas o de defensa de sus intereses. Su presencia sobre esa sociedad hubo de trasladarse a modalidades privadas, como la correspondencia, o simbólicas, como las ceremonias, donde ellas permanecían como asistentes invisibles, pero activos en lo organizativo y en el espacio sonoro, a través del canto u otros medios. Los pliegos de profesión, aun costeados por las familias o benefactores de la profesa, formaron parte de la actualización de su existencia que las comunidades religiosas tenían que hacer sobre la sociedad de su entorno, a la que recordaban su funcionalidad, valores y objetivos simbólicos. Si por un lado procuran el halago de la nueva monja y por ende de su familia, por otro dan sentido a su gesto de renuncia a lo mundano al convertir el monasterio en un reducto de valores superiores a los del entorno y, en ese aspecto, merecedor de respeto, atención y recursos. Los textos de estos pliegos forman parte de ese sistema de comunicación diferida, simbólicamente cifrada, entre el convento y la sociedad, de modo que nos permiten explorar cómo comprende la sociedad el acto de profesión, qué mensaje transmite a 
las mujeres y a su vez cómo el colectivo conventual entiende su renuncia al mundo, ya que ambos aspectos se interrelacionan en estos textos.

Esta cuestión tendrá que ser examinada junto con otras muchas que aún quedan pendientes de dilucidar sobre este subgénero, que se levanta entre los intereses críticos de la música, la literatura, la imprenta, la historia cultural, religiosa y de género. En cada uno de ellos tendrán que recorrerse caminos largos para llegar a su completo conocimiento.

\section{BiBLIOGRAFÍA}

Ma Soterrańa Aguirre Rincón, «Sonidos en el silencio. Monjas y música en la España de 1550 a 1650», en Javier Suárez Pajares y John Griffiths (dirs.), Politicas y prácticas musicales en el mundo de Felipe II. Estudios sobre la música en España, sus instituciones y sus territorios en la segunda mitad del siglo XVI, Madrid, Instituto Complutense de Ciencias Musicales, 2004, p. 285-318.

Ma Carmen Alarcón Román (ed.), Sor Francisca de Santa Teresa. Coloquios, Sevilla, ArCiBel, 2007.

Ana de San Bartolomé, Obras completas, Julián Urkiza (ed.), Burgos, Monte Carmelo, 1998.

Andrea Bombi, «"The third villancico was a motet”: the villancico and related genres», en Tess Knighton y Álvaro Torrente (eds.), Devotional Music in the Iberian World, 1450-1800: the Villancico and Related Genres, Aldershot, Hampshire, Ashgate, 2007, p. 149-187.

Giovanna Bosi Maramotti, Le muse d'Imeneo. Metamorfosi letteraria dei libretti per nozze dal '500 al '900, Ravenna, Edizioni del Girasole, 1995.

Paulino Capdepón Verdú, «La capilla musical del monasterio de las Descalzas Reales de Madrid", Anales del Instituto de Estudios Madrileños, 1997, 37, p. 216-226.

Catálogo de villancicos de la Biblioteca Nacional. Siglo XVII, Madrid, Ministerio de Cultura, 1992.

Catálogo de villancicos y oratorios en la Biblioteca Nacional. Siglos XVIII y XIX, Madrid, Ministerio de Cultura, 1990.

Cecilia del Nacimiento, Obras completas, José M. Díaz Cerón (ed.), Madrid, Espiritualidad, 1971.

José Climent Barber, Villancico barroco valenciano, Valencia, Consell Valencià de Cultura, 1997.

Antonio Cruz Casado, "Villancicos barrocos andaluces para diversas fiestas del convento de Santa Clara de Montilla (1684-1737)», en Manuel Peláez del Rosal (coord.), El franciscanismo en Andalucia: conferencias del I Curso de verano sobre el franciscanismo en Andalucía (Priego de Córdoba, 7 a 12 de agosto de 1995), Córdoba, Caja de Ahorros y Monte de Piedad de Córdoba, 1997, p. 325-346. 
Cristina Fernandes, «A música no contexto da cerimonia da Profissão nos mosteiros femininos portugueses (1768-1828)», Revista Portuguesa de musicologia, 19971998, 7-8, p. 59-94.

Javier Garbayo Montabes, «La hagiografía a través de los fondos musicales de las catedrales y colegiatas españolas: himnos, secuencias, villancicos y otras composiciones de loas en honor de los santos», Memoria Ecclesiae, 2005, 26, p. 53-105 [Hagiografia y archivos de la iglesia. Santoral hispano-mozárabe en las diócesis de España].

Ma Cruz García de Enterría, «Literatura de cordel en tiempos de Carlos II: géneros parateatrales», Diálogos hispánicos de Amsterdam. El teatro español a fines del siglo XVII, Amsterdam, Rodopi, 1989, I, p. 137-154.

Ma Cruz García de Enterría, «Los pliegos de villancicos como literatura efímera», [Atti del seminario su "La scrittura dell'effimero" (Cagliari, 11-13 maggio, 1995)] Studi Ispanici, 1994-1996, p. 129-145.

Víctor García de la Concha y Ana Ma Álvarez Pellitero (eds.), Libro de Romances y Coplas del Carmelo de Valladolid:(c.1590-1606), Salamanca, Consejo General de Castilla y León, Servicio de Publicaciones, 1982, 2 vols.

María Gembero Ustárroz, "De rosas cercada: music by Francisco de la Huerta for the nuns of Santa Ana de Ávila (1767-78)», en Tess Knighton y Álvaro Torrente (eds.), Devotional Music in the Iberian World, 1450-1800: the Villancico and Related Genres, Aldershot, Hampshire, Ashgate, 2007, p. 321-332.

Fernán González de Eslava, Villancicos, romances, ensaladas y otras canciones devotas, Margit Frenk (ed.), México, el Colegio de México, 1989.

Juan Antonio Hormigón (coord.), Autoras en la historia del teatro español (15001994). Volumen I (siglos XVII-XVIII-XIX), Madrid, Publicaciones de la Asociación de Directores de Escena de España, 1996.

José Pío Tejera, Biblioteca del murciano o ensayo de un diccionario biográfico y bibliográfico de la literatura en Murcia, Madrid, Tip. de la Revista de Archivos, Bibliotecas y Museos, 1922.

Juana Inés de la Cruz, Obras completas, Alfonso Méndez Plancarte (ed.), México, Fondo de Cultura Económica, 1952. t. 2.

Tess Knighton y Álvaro Torrente (eds.), Devotional music in the Iberian world, 14501800 : the villancico and related genres, Aldershot, Hampshire, Ashgate, 2007.

Paul R. Laird, Towards a History of the Spanish Villancico, Warren, Mich., Harmonie Park Press, 1997.

Manuel de León Marchante, Obras poeticas pósthumas, que a diversos assumptos escrivió... Poesias sagradas. Tomo segundo, Madrid, Gabriel del Barrio, 1733.

Ma Pilar Manero Sorolla, "La poesía de María de san José (Salazar)», Homenaje a Georgina Sabat-Rivers, Madrid, Castalia, 1992, p. 187-222.

María de Santa Isabel (Marcia Belisarda), Poesías, Madrid, Biblioteca Nacional, Ms. 7469.

Gabriele Mazzucco, «Discorsi e poesie per monache stampati a Venezia nel secolo XVIII», Benedictina, 1985, 32, p. 161-200. 
Melchor de Santa Ana, Chronica de carmelitas descalças particular do Reyno de Portgual, Lisboa, 1657, vol. I.

Jesús Menéndez Peláez, Nueva visión del amor cortés, Oviedo, Universidad de Oviedo, 1980.

René Metz, Consécration des Vierges dans l'Eglise Romaine. Etude d'Histoire de la Liturgie, Paris, Presses Universitaires de France, 1954.

Craig A. Monson, Disembodied voices. Music and Culture in an Early Modern Italian Convent, Berkeley, University of California Press, 1995.

Matilde Olarte, «Las 'Monjas Músicas' en los conventos españoles del Barroco. Una aproximación etnohistórica», Revista de Folklore, 1993, 146, p. 56-63.

Olga Pinto, Nuptialia. Saggio di bibliografia di scritti italiani pubblicati per nozze dal 1484 al 1799, Firenze: Olschki, 1971.

Juan Rufo, Las seiscientas apotegmas y otras obras en verso, Alberto Blecua (ed.), Madrid, Espasa-Calpe, 1972.

Leticia Sánchez Hernández, Patronato regio y órdenes religiosas femeninas en el Madrid de los Austrias, Madrid, Fundación Universitaria Española, 1997.

Monserrat Sánchez Sicart, Guía histórica de la música en Madrid, Madrid, Comunidad, 2001.

Vicente Sánchez, La lira poética, Jesús Duce García (ed.), Zaragoza, PUZ, 2003.

Antonio Sánchez Romeralo, El villancico, Madrid, Gredos, 1969.

María Sanhuesa Fonseca, "Música de señoras: las religiosas y la teoría musical española del siglo XVII», en Francisco Javier Campos y Fernández de Sevilla (coord.) La clausura femenina en España: actas del simposium: 1/4-IX-2004, Madrid, Real Centro Universitario Escorial- Ma Cristina, 2004, p. 167-180.

Stacey Schlau, Viva al siglo, muerta al mundo: selected works by / Obras escogidas de Maria de San Alberto, New Orleans, University Press of the South, 1998.

Valentì Serra de Manresa (ofm. cap.), Les Clarisses-Caputxines a Catalunya i Mallorca: de la fundació a la guerra civil (1599-1939), Barcelona, Facultat de Teologia de Catalunya, 2002.

Martha Lilia Tenorio, Los villancicos de sor Juana, México, El Colegio de México, 1999.

Teresa de Jesús, Obras completas, E. Llamas (ed.), Madrid, Editorial de Espiritualidad, 2000.

Álvaro Torrente y Janet Hathaway, Pliegos de villancicos en la Hispanic Society of America y la New York Public Library, Kassel, Reichenberger, 2007.

Álvaro Torrente y Miguel Ángel Marín, Pliegos de villancicos en la British Library (Londres) y la University Library (Cambridge), Kassel, Reichenberger. 2000.

Miguel Ángel Marín, «A propósito de la reutilización de textos de villancicos: dos colecciones desconocidas de pliegos impresos en la British Library (ss. XVIXVIII)", Revista de musicología, 2000, XXIII, 1, p. 103-130.

Violante do Ceo, Parnaso lusitano de divinos e humanos versos..., Lisboa, Miguel Rodrigues, 1732-1733, 2 ts. 


\section{BULLETIN HISPANIQUE}

M. A. Virgili Blanquet, G. Vega García-Luengos y C. Caballero Fernández-Rufete (eds.), Música y literatura en la peninsula ibérica: 1600-1750. Actas del Congreso Internacional. Valladolid, 20, 21 y 22 de febrero, 1995, Valladolid, Junta de Castilla y León, Universidad de Valladolid, 1997.

Francisco Zaragoza Ayarza, "Francisco Diego de Sayas Rabanera y Ortubia, historiador de la Almunia de Dońa Godina (1598-1678)», Rolde. Revista de cultura aragonesa, 2009, 129, p. 6-11.

Luis Ignacio Zevallos, Chrónica del observantíssimo convento de madres capuchinas de la exaltación del Santísimo Sacramento en la ciudad de Murcia, Madrid, Vda. de Pedro Enguera, 1736, 2 vols. 